OPEN ACCESS

Edited by:

Karsten Kretschmer,

CRTD/DFG-Center for

Regenerative Therapies Dresden,

Germany

Reviewed by:

Ari Waisman,

Johannes Gutenberg-

Universität Mainz, Germany

Thomas Korn,

Technische Universität

München, Germany

*Correspondence:

Daniel Hawiger

dhawiger@s/u.edu

Specialty section:

This article was submitted

to Immunological Tolerance

and Regulation,

a section of the journal

Frontiers in Immunology

Received: 25 March 2017

Accepted: 21 April 2017

Published: 09 May 2017

Citation:

Jones A and Hawiger D (2017)

Peripherally Induced Regulatory $T$ Cells: Recruited Protectors of

the Central Nervous System against Autoimmune Neuroinflammation.

Front. Immunol. 8:532. doi: 10.3389/fimmu.2017.00532

\section{Peripherally Induced Regulatory T Cells: Recruited Protectors of the Central Nervous System against Autoimmune Neuroinflammation}

\author{
Andrew Jones and Daniel Hawiger* \\ Department of Molecular Microbiology and Immunology, Saint Louis University School of Medicine, St. Louis, MO, USA
}

Defects in regulatory T cells (Treg cells) aggravate multiple sclerosis (MS) after its onset and the absence of Treg cell functions can also exacerbate the course of disease in an animal model of MS. However, autoimmune neuroinflammation in many MS models can be acutely provoked in healthy animals leading to an activation of encephalitogenic $T$ cells despite the induction of immune tolerance in the thymus including thymically produced (t)Treg cells. In contrast, neuroinflammation can be ameliorated or even completely prevented by the antigen-specific Treg cells formed extrathymically in the peripheral immune system (pTreg cells) during tolerogenic responses to relevant neuronal antigens. This review discusses the specific roles of Treg cells in blocking neuroinflammation, examines the impact of peripheral tolerance and dendritic cells on a relevant regulation of neuroinflammation, and explores some of the most recent advances in elucidation of specific mechanisms of the conversion and function of pTreg cells including the roles of CD5 and Hopx in these processes.

Keywords: experimental autoimmune encephalomyelitis/multiple sclerosis, neuroinflammation, pTreg cells, Treg cells, tolerance, dendritic cells, CD5, HOPX

\section{THE ROLE OF IMMUNE REGULATION IN MULTIPLE SCLEROSIS (MS) AND ITS ANIMAL MODEL}

During MS, immune cells attack components of the myelin sheath that surrounds the neuronal axons of the nerves of the central nervous system (CNS) leading to severe neurological symptoms. The specific autoimmune mechanisms underlying MS involve unchecked activation of autoreactive $\mathrm{T}$ cells $(1,2)$. Neuronal antigens present in the periphery may first prime the encephalitogenic $\mathrm{T}$ cells that subsequently migrate into the CNS where, upon re-encountering their cognate antigens, they release pro-inflammatory molecules mediating neuronal damage $(1,2)$. Many crucial studies on the pathogenesis and possible treatments of MS have been carried out using a mouse model of autoimmune CNS disease that in many ways mimics MS, experimental autoimmune encephalomyelitis (EAE) induced by immunization with various neuronal antigens such as myelin oligodendrocyte glycoprotein (MOG), myelin basic protein (MBP), and proteolipid protein (PLP) (3-7). The characteristic inflammation seen in EAE with perivascular $\mathrm{CD} 4^{+} \mathrm{T}$ cell and mononuclear cell inflammation, the clinical symptoms of progressive ascending paralysis, and the relative ease of disease induction make EAE a relevant model for MS and also a powerful model for the study of immune regulation of Th1- and Th17-dependent autoimmunity $(8,9)$. 
Healthy individuals have myelin reactive $\mathrm{T}$ cells in their system, albeit, at a lower frequency than MS patients, indicating that mechanisms are in place to control these myelin-reactive T cells and prevent MS (10). Immunomodulation and Foxp3 ${ }^{+}$ regulatory T cells (Treg cells) play a pivotal role in protection and recovery from EAE and MS by suppressing autoreactive T cells and either the absence of tTreg cells or their abnormal functions can exacerbate the severity of EAE (11-16). In addition to classically described $\mathrm{CD} 4^{+} \mathrm{CD} 25^{+}$Foxp $3^{+}$Treg cells, Foxp $3^{\text {neg }} \operatorname{Tr} 1$ cells, regulatory $\mathrm{B}$ cells, and $\mathrm{CD} 8^{+}$regulatory $\mathrm{T}$ cells may have various roles in regulating different aspects of the autoimmune response in EAE as discussed in Ref. (17-22). The initial observations indicating a role of Treg cells in inhibition of CNS inflammation came from experiments that showed a suppressive cell population arising during the recovery stage of EAE that was able to prevent EAE and suppress T effector cells when transferred into healthy animals (23-26). It has subsequently been shown that a transfer of in vitro-induced Treg cells could ameliorate EAE (27). Studies by Lafaille and colleagues showed that MBP T cell receptor (TCR) transgenic mice crossed onto a RAG-deficient background that precluded a development of Treg cells succumbed to spontaneous EAE (28). Correspondingly, a depletion of Treg cells in vivo by anti-CD25 antibody exacerbates EAE (29). In the early stages of MS, patients have the same frequency of Treg cells in their peripheral blood although frequencies of Treg cells are increased in the cerebrospinal fluid (CSF) of MS patients $(30,31)$. However, in patients suffering from MS, Treg cells may have a reduced capacity for suppression and this functional defect has been implicated in the pathogenesis of MS (30-36). Therefore, therapies focused on functions of Treg cells have been proposed as an excellent approach to block neuroinflammation some of which are reviewed in Ref. $(13,37,38)$.

\section{PERIPHERALLY INDUCED REGULATORY T CELLS PROTECTING FROM EAE}

A majority of Foxp $3^{+}$regulatory $\mathrm{T}$ cells develop in the thymus and such Treg cells are indispensable for the maintenance of immune homeostasis (39-42). However, the sudden onset of the autoimmune disease is not known to be preceded by perceivable perturbations in the functions of Treg cells despite the recognized genetic associations between $\mathrm{T}$ cell-related genes and MS as well as known defects in the functions of Treg cells implicated in the pathogenesis of MS $(15,43-45)$. Therefore, despite their crucial role in mitigation of the ongoing neuroinflammatory disease and preventing spontaneous autoimmunity in some MS models, the mechanisms dependent on thymically produced tTreg cells appear insufficient to prevent the initial priming of encephalithogenic T cells and block EAE after an immunization with relevant neuronal antigens $(3,4,46-50)$. Similarly, although depletion of Treg cells inhibits spontaneous recovery from EAE, some expanding Treg cells that accumulate in CNS during EAE may not be fully efficient in controlling autoimmunity due to various reasons including possible resistance of effector $\mathrm{T}$ cells to Treg-mediated suppression $(48,51-53)$. Overall, the regulatory capacity of tTreg cells can be overwhelmed by the inflammatory injury acutely induced in healthy animals resembling the sudden onset of MS in patients.

However, EAE can be effectively prevented by the preadministration of neuronal antigens in the non-inflammatory context. The first indication of such actively induced tolerance was provided in 1958 by a group who showed that a form of EAE could be prevented by previous administration of autoantigen in incomplete Freund's adjuvant (IFA) (54). Further, lymph node cells transferred from rats that were treated with MBP administered without pro-inflammatory adjuvant protected recipient rats from a subsequently induced EAE (55). These early observations were then expanded in the context of the mechanisms responsible for the induction of extrathymic peripheral tolerance $(56,57)$. Extensive work by Stephen Miller and his co-workers showed that mouse spinal cord homogenates as well as various purified myelin derived peptides chemically coupled to splenocytes induced immune tolerance that prevented subsequently induced EAE (58-61). Additionally, tolerance preventing EAE could also be induced by microparticles that mimic apoptotic cells bearing myelin antigens (62). The $\mathrm{T}$ cell tolerance induced by neuronal antigenic materials relied on various immunological mechanisms including T cell anergy, however, functions of Treg cells were particularly important for the long-term maintenance of this induced tolerance $(62,63)$. Work by other investigators showed that treatment with tolerogenic antigens and also presentation to T cells of MOG and PLP by extrathymic dendritic cells (DCs) of the peripheral immune system could specifically prevent EAE and also increase the numbers of Treg cells (64-68). In non-EAE experimental models, DCs can convert pTreg cells de novo in addition to increasing the numbers and enhancing the functions of pre-existing Foxp $3^{+} \mathrm{CD} 25^{+}$tTreg cells (69-75). Therefore, despite some clear indications of a de novo induction of pTreg cells, it remained unclear whether the newly converted pTreg cells were indispensible to prevent symptoms of EAE $(63,65,67,68,76)$. Results of recent experiments using Hop $x^{-/-}$ mice with specific deficiencies in the functions and survival of pTreg cells but not tTreg cells helped to resolve this issue $(77,78)$. The severity of the EAE is the same in Hopx $x^{-/-}$and Hopx $x^{+/+}$ mice consistent with the unaltered functions of their tTreg cells $(77,78)$. However, following treatment with tolerizing myelin antigens, the $H_{o p} x^{-/-}$mice are unable to maintain long-lasting tolerance that prevents a subsequent induction of EAE (78). This defect is caused by altered suppressor functions and an increased death of $H o p x^{-/-}$pTreg cells after their normal conversion from the anergic $\mathrm{T}$ cells following the responses to tolerogenic antigens. However, peripheral tolerance in $H_{o p} x^{-/-}$mice can be completely restored by transferred Hop $x^{+/+}$Foxp $3^{\text {neg }}$ precursors that give rise to functional pTreg cells (78). In contrast, a transfer of similar numbers of pre-existing Hop $x^{+/+}$Foxp $3^{+}$tTreg cells fails to restore tolerance and prevention of EAE in $H_{o p x^{-/-}}$mice following a treatment with tolerizing myelin antigens (78). Hopx-sufficient pTreg cells are stable and maintain Foxp3 expression also under pro-inflammatory conditions $(78,79)$. In agreement with the crucial roles of such de novo differentiated pTreg cells that convert from the initially tolerized $\mathrm{T}$ cells, a deletion of Treg cells does not interfere with the initial induction of tolerance that depends on anergic T cells, but instead, it 
breaks the long-lasting maintenance of such tolerance that relies on pTreg cells that develop from the initially tolerized $\mathrm{T}$ cells $(63,78)$. Further, the induction of the pTreg cell-dependent tolerance and protection from EAE is compromised in the absence of CD5 that is required in $\mathrm{T}$ cells for their efficient conversion into pTreg cells (80). Similar, antigenic presentation by DCs in the absence of the pathways that increase expression of CD5 in T cells also fails to induce pTreg cells and to maintain long-lasting tolerance (79). Overall, consistent with a known division of labor between tTreg cells and pTreg cells proposed to help determine the outcomes of general auto-inflammatory responses, maternal-fetal conflict, and mucosal tolerance, pTreg cells and tTreg cells have complementary but also separate functions in regulation of neuroinflammation $(75,78,81-84)$.

\section{MECHANISMS RESPONSIBLE FOR INDUCTION OF pTreg CELLS}

In contrast to pre-existing tTreg cells, antigen-specific pTreg cells first need to be converted extrathymically from the Foxp $3^{\text {neg }}$ precursors through the mechanisms of peripheral tolerance. In the absence of this active de novo conversion of pTreg cells, animals remain fully susceptible to EAE similar to what is observed in mice that have a global genetic deficiency preventing either extrathymic generation of such pTreg cells or their functions and survival $(75,78)$. Although multiple types of APCs may have tolerogenic functions in EAE including macrophages $(62,63)$, DCs are particularly well equipped to regulate immune responses (85-88). In the steady state, defined by the absence of pro-inflammatory stimuli, the outcome of $\mathrm{T}$ cell activation by DCs results in T cell tolerance $(85,89-91)$. DCs first pulsed with neuronal antigens ex vivo and then re-injected into animals could prevent EAE similar to soluble tolerogenic antigens that can also be picked up by DCs in vivo (92-94). The anti-EAE tolerance is mediated by the inherent functions of endogenous DCs and an experimental induction of such tolerance was first achieved by delivering MOG in vivo using recombinant chimeric antibodies specific for DEC205 expressed on DCs (64). Overall, the experimental targeting to DCs or expression in DCs of MOG and other neuronal antigens has been established to induce antiEAE tolerance $(64,66-68,76,78,79)$. As part of their tolerogenic program, DCs induce a de novo induction of Foxp3 expression in extrathymic T cells converting them into pTreg cells and such pTreg cells were then also found to protect from EAE (68-72, $78,79,95)$. Tolerogenic DCs are characterized by production of various immunomodulatory metabolites and cytokines including TGF-beta and retinoic acid (70, 96-100). The tolerogenic functions of DCs can also be facilitated by the engagement of specific immunomodulatory molecules such as CTLA-4 and PD-L1 $(67,101-105)$. In addition to the pathways that directly affect the cell-intrinsic induction of Foxp3 expression, induction of immune tolerance and pTreg cells also depends on the specificity of T cells to self and tolerizing antigens $(83,106,107)$. Such antigenic specificity is reflected by CD5, a complex regulator of T cell signaling whose expression in T cells parallels TCR signal strength during thymic selection of self-reactive $\mathrm{T}$ cells
(108-111). Recently, CD5 was shown to instruct the extrathymic conversion of self-reactive $\mathrm{CD} 5^{\text {hi }} \mathrm{T}$ cells into pTreg cells by modulating their responsiveness to effector cell-differentiating cytokines through blocking the activation of the mechanistic target of rapamycin (80). In addition to thymic mechanisms, expression of CD5 in T cells can also be increased extrathymically to promote conversion of pTreg cells by tolerogenic BTLA ${ }^{\text {hi }}$ DCs through engagement of HVEM, a receptor for BTLA (79). Overall, CD5 increases a probability of pTreg cell conversion from $\mathrm{T}$ cells that have responded to either high-affinity selfpeptide-MHC in the thymus or to tolerizing antigens presented by DCs of the peripheral immune system, and this mechanism may facilitate a specific formation of pTreg cells especially in the presence of pro-inflammatory cytokines $(79,80)$.

\section{THE SUPPRESSOR MECHANISMS OF Treg CELLS RELEVANT TO INHIBITION OF MS AND EAE}

There are multiple molecular mechanisms of immune suppression by Treg cells as excellently described in Ref. $(37,112-114)$ and others. The Treg cells isolated from MS patients have generally been shown defective in their ability to suppress effector $\mathrm{T}$ cell responses and some of such Treg cells have also a decreased expression of crucial CTLA-4 as well as Foxp3 $(30-36,115,116)$. In another mechanism, CD39 expressed by Treg cells removes inflammatory ATP by converting it into AMP, a substrate for CD73 that is expressed by human Th17 cells, astrocytes, and endothelial cells of the blood-brain barrier (15, 100, 117-125). Therefore, a lower frequency of CD39+ Treg cells in MS patients may contribute to a defective suppression in MS (119). Other surface molecules expressed by Treg cells that have been shown to modulate immune suppression include Neuropilin-1, LAG-3, TIM-3, and TIGIT (126-137). Human Treg cells also suppress effector $\mathrm{T}$ cells by interfering with $\mathrm{Ca} 2^{+}$signaling in effector $\mathrm{T}$ cells and this suppressor function appears to be defective in Treg cells in some MS patients as well $(134,136,138,139)$. In addition to various functional deficits, the Treg cells found in MS patients may acquire the proinflammatory phenotype of effector $\mathrm{T}$ cells. David Hafler's group showed that MS patients have increased Th1 Treg cells that express IFN- $\gamma$, TBX21, and CXCR3 (140). Overall, it is clear that defects in Treg cell functions exacerbate the course of MS and could drive disease progression.

It remains unclear if the crucial molecular mechanisms of suppression differ between tTreg cells and pTreg cells. Although Hopx is expressed in both tTreg cells and pTreg cells, only pTreg cell functions and survival rely on Hopx $(77,78)$. The relevant molecular pathways controlled by Hopx in pTreg cells remain incompletely understood but Hopx can block expression of IL-2 in these cells (78). Treg cells, in general, rely on extracellular sources of IL-2 for their proliferation and survival and a treatment with recombinant IL-2 promotes proliferation and functions of regulatory $\mathrm{T}$ cells although high doses of recombinant IL-2 in vivo can also lead to a disappearance of Treg cell populations despite their initial expansion $(53,112,141-148)$. In the absence of Hopx, pTreg cells have increased expression of the intrinsic IL-2 
coinciding with their decreased suppressor ability and increased cell death. The normal functions of $\mathrm{Hopx}^{-/-}$pTreg cells can be restored by genetically ablating IL-2 expression, suggesting that increased intrinsic IL-2 expression in the absence of Hopx may be detrimental in pTreg cells (78). However, since Hopx directly modulates the expression of the AP-1 transcription complex in pTreg cells and also possibly affects other molecular pathways, the relevant complex functions of Hopx may likely be context dependent and involve other mechanisms that directly modulate pTreg cell responses (77).

\section{CONCLUSION}

Studies using EAE have helped to define the pathology associated with the human disease MS and helped establish that Treg cells are vital to prevent CNS autoinflammation. Currently used therapies for MS are still not curative and often produce harmful side effects $(38,149-152)$. Therefore, achieving tolerance through

\section{REFERENCES}

1. Compston A, Coles A. Multiple sclerosis. Lancet (2008) 372(9648):1502-17. doi:10.1016/S0140-6736(08)61620-7

2. Dendrou CA, Fugger L, Friese MA. Immunopathology of multiple sclerosis. Nat Rev Immunol (2015) 15(9):545-58. doi:10.1038/nri3871

3. Smilek DE, Gautam AM, Pearson C, Steinman L, McDevitt HO. EAE: a model for immune intervention with synthetic peptides. Int Rev Immunol (1992) 9(3):223-30. doi:10.3109/08830189209061792

4. Mendel I, Kerlero de Rosbo N, Ben-Nun A. A myelin oligodendrocyte glycoprotein peptide induces typical chronic experimental autoimmune encephalomyelitis in $\mathrm{H}-2 \mathrm{~b}$ mice: fine specificity and $\mathrm{T}$ cell receptor $\mathrm{V}$ beta expression of encephalitogenic T cells. Eur J Immunol (1995) 25(7):1951-9. doi:10.1002/eji.1830250723

5. Kuchroo VK, Anderson AC, Waldner H, Munder M, Bettelli E, Nicholson LB. T cell response in experimental autoimmune encephalomyelitis (EAE): role of self and cross-reactive antigens in shaping, tuning, and regulating the autopathogenic T cell repertoire. Annu Rev Immunol (2002) 20:101-23. doi:10.1146/annurev.immunol.20.081701.141316

6. McMahon EJ, Bailey SL, Castenada CV, Waldner H, Miller SD. Epitope spreading initiates in the CNS in two mouse models of multiple sclerosis. Nat Med (2005) 11(3):335-9. doi:10.1038/nm1202

7. Simmons SB, Pierson ER, Lee SY, Goverman JM. Modeling the heterogeneity of multiple sclerosis in animals. Trends Immunol (2013) 34(8):410-22. doi:10.1016/j.it.2013.04.006

8. Miller SD, Karpus WJ. Experimental autoimmune encephalomyelitis in the mouse. Curr Protoc Immunol (2007) Chapter 15:Unit 15.1. doi:10.1002/ 0471142735.im1501s77

9. Miller SD, Karpus WJ, Davidson TS. Experimental autoimmune encephalomyelitis in the mouse. Curr Protoc Immunol (2010) Chapter 15:Unit 15.1. doi:10.1002/0471142735.im1501s88

10. Raddassi K, Kent SC, Yang J, Bourcier K, Bradshaw EM, Seyfert-Margolis V, et al. Increased frequencies of myelin oligodendrocyte glycoprotein/MHC class II-binding CD4 cells in patients with multiple sclerosis. J Immunol (2011) 187(2):1039-46. doi:10.4049/jimmunol.1001543

11. Hilliard BA, Kamoun M, Ventura E, Rostami A. Mechanisms of suppression of experimental autoimmune encephalomyelitis by intravenous administration of myelin basic protein: role of regulatory spleen cells. Exp Mol Pathol (2000) 68(1):29-37. doi:10.1006/exmp.1999.2290

12. McHugh RS, Shevach EM. The role of suppressor $\mathrm{T}$ cells in regulation of immune responses. J Allergy Clin Immunol (2002) 110(5):693-702. doi:10.1067/mai.2002.129339

13. O'Connor RA, Anderton SM. Foxp3+ regulatory T cells in the control of experimental CNS autoimmune disease. J Neuroimmunol (2008) 193(1-2): 1-11. doi:10.1016/j.jneuroim.2007.11.016 de novo-induced pTreg cells that are specific for various myelin antigens might be an attractive option to effectively treat MS in addition to efforts focused on enhancing the functions of already existing Treg cells during the course of disease.

\section{AUTHOR CONTRIBUTIONS}

Both authors wrote and approved the final version of the manuscript.

\section{FUNDING}

This work was supported in part by grants from the National Multiple Sclerosis Society (RG5019A) and National Institute of Allergy and Infectious Diseases of the National Institutes of Health (R01AI113903) (both to DH). This publication is solely the responsibility of the authors and does not necessarily represent the official view of the National Institutes of Health.

14. Lowther DE, Hafler DA. Regulatory T cells in the central nervous system. Immunol Rev (2012) 248(1):156-69. doi:10.1111/j.1600-065X.2012.01130.x

15. Kleinewietfeld M, Hafler DA. Regulatory T cells in autoimmune neuroinflammation. Immunol Rev (2014) 259(1):231-44. doi:10.1111/imr.12169

16. Vahl JC, Drees C, Heger K, Heink S, Fischer JC, Nedjic J, et al. Continuous $\mathrm{T}$ cell receptor signals maintain a functional regulatory $\mathrm{T}$ cell pool. Immunity (2014) 41(5):722-36. doi:10.1016/j.immuni.2014.10.012

17. Brusko TM, Putnam AL, Bluestone JA. Human regulatory T cells: role in autoimmune disease and therapeutic opportunities. Immunol Rev (2008) 223:371-90. doi:10.1111/j.1600-065X.2008.00637.x

18. Pot C, Apetoh L, Kuchroo VK. Type 1 regulatory T cells $(\operatorname{Tr} 1)$ in autoimmunity. Semin Immunol (2011) 23(3):202-8. doi:10.1016/j.smim.2011.07.005

19. Mann MK, Ray A, Basu S, Karp CL, Dittel BN. Pathogenic and regulatory roles for B cells in experimental autoimmune encephalomyelitis. Autoimmunity (2012) 45(5):388-99. doi:10.3109/08916934.2012.665523

20. Gravano DM, Hoyer KK. Promotion and prevention of autoimmune disease by CD8+ T cells. J Autoimmun (2013) 45:68-79. doi:10.1016/j.jaut. 2013.06.004

21. Pennati A, Ng S, Wu Y, Murphy JR, Deng J, Rangaraju S, et al. Regulatory $B$ cells induce formation of IL-10-expressing $\mathrm{T}$ cells in mice with autoimmune neuroinflammation. J Neurosci (2016) 36(50):12598-610. doi:10.1523/ JNEUROSCI.1994-16.2016

22. Wang X, Zhang J, Baylink DJ, Li CH, Watts DM, Xu Y, et al. Targeting non-classical myelin epitopes to treat experimental autoimmune encephalomyelitis. Sci Rep (2016) 6:36064. doi:10.1038/srep36064

23. Adda DH, Beraud E, Depieds R. Evidence for suppressor cells in Lewis rats' experimental allergic encephalomyelitis. Eur J Immunol (1977) 7(9):620-3. doi:10.1002/eji.1830070908

24. Adda DH, Beraud E, Depieds R. [Suppressor cells in allergic encephalomyelitis]. Ann Immunol (Paris) (1977) 128(1-2):241-2.

25. Killen JA, Swanborg RH. Regulation of experimental allergic encephalomyelitis. Part 4. Further characterization of postrecovery suppressor cells. J Neuroimmunol (1982) 3(2):159-66. doi:10.1016/0165-5728(82)90049-2

26. Karpus WJ, Swanborg RH. CD4+ suppressor cells differentially affect the production of IFN-gamma by effector cells of experimental autoimmune encephalomyelitis. J Immunol (1989) 143(11):3492-7.

27. Kohm AP, Carpentier PA, Anger HA, Miller SD. Cutting edge: CD4+CD25+ regulatory $\mathrm{T}$ cells suppress antigen-specific autoreactive immune responses and central nervous system inflammation during active experimental autoimmune encephalomyelitis. J Immunol (2002) 169(9):4712-6. doi:10.4049/ jimmunol.169.9.4712

28. Lafaille JJ, Nagashima K, Katsuki M, Tonegawa S. High incidence of spontaneous autoimmune encephalomyelitis in immunodeficient anti-myelin basic protein T cell receptor transgenic mice. Cell (1994) 78(3):399-408. doi:10.1016/0092-8674(94)90419-7 
29. Kohm AP, McMahon JS, Podojil JR, Begolka WS, DeGutes M, Kasprowicz DJ, et al. Cutting edge: anti-CD25 monoclonal antibody injection results in the functional inactivation, not depletion, of CD4+CD25+ T regulatory cells. J Immunol (2006) 176(6):3301-5. doi:10.4049/jimmunol.176.6.3301

30. Feger U, Luther C, Poeschel S, Melms A, Tolosa E, Wiendl H. Increased frequency of CD4+ CD25+ regulatory $\mathrm{T}$ cells in the cerebrospinal fluid but not in the blood of multiple sclerosis patients. Clin Exp Immunol (2007) 147(3):412-8. doi:10.1111/j.1365-2249.2006.03271.x

31. Venken K, Hellings N, Thewissen M, Somers V, Hensen K, Rummens JL, et al. Compromised CD4+ CD25(high) regulatory T-cell function in patients with relapsing-remitting multiple sclerosis is correlated with a reduced frequency of FOXP3-positive cells and reduced FOXP3 expression at the single-cell level. Immunology (2008) 123(1):79-89. doi:10.1111/j.1365-2567.2007.02690.x

32. Haas J, Hug A, Viehover A, Fritzsching B, Falk CS, Filser A, et al. Reduced suppressive effect of $\mathrm{CD} 4+\mathrm{CD} 25$ high regulatory $\mathrm{T}$ cells on the $\mathrm{T}$ cell immune response against myelin oligodendrocyte glycoprotein in patients with multiple sclerosis. Eur J Immunol (2005) 35(11):3343-52. doi:10.1002/ eji.200526065

33. Kumar M, Putzki N, Limmroth V, Remus R, Lindemann M, Knop D, et al. $\mathrm{CD} 4+\mathrm{CD} 25+\mathrm{FoxP} 3+\mathrm{T}$ lymphocytes fail to suppress myelin basic proteininduced proliferation in patients with multiple sclerosis. J Neuroimmunol (2006) 180(1-2):178-84. doi:10.1016/j.jneuroim.2006.08.003

34. Venken K, Hellings N, Hensen K, Rummens JL, Medaer R, D’Hooghe MB, et al. Secondary progressive in contrast to relapsing-remitting multiple sclerosis patients show a normal CD4+CD25+ regulatory T-cell function and FOXP3 expression. J Neurosci Res (2006) 83(8):1432-46. doi:10.1002/ jnr.20852

35. Venken K, Hellings N, Broekmans T, Hensen K, Rummens JL, Stinissen P. Natural naive CD4+CD25+CD127low regulatory T cell (Treg) development and function are disturbed in multiple sclerosis patients: recovery of memory Treg homeostasis during disease progression. J Immunol (2008) 180(9): 6411-20. doi:10.4049/jimmunol.180.9.6411

36. Frisullo G, Nociti V, Iorio R, Patanella AK, Caggiula M, Marti A, et al. Regulatory $\mathrm{T}$ cells fail to suppress $\mathrm{CD} 4 \mathrm{~T}+$-bet+ $\mathrm{T}$ cells in relapsing multiple sclerosis patients. Immunology (2009) 127(3):418-28. doi:10.1111/ j.1365-2567.2008.02963.x

37. Spence A, Klementowicz JE, Bluestone JA, Tang Q. Targeting Treg signaling for the treatment of autoimmune diseases. Curr Opin Immunol (2015) 37:11-20. doi:10.1016/j.coi.2015.09.002

38. Cheng Y, Sun L, Xie Z, Fan X, Cao Q, Han J, et al. Diversity of immune cell types in multiple sclerosis and its animal model: pathological and therapeutic implications. J Neurosci Res (2017). doi:10.1002/jnr.24023

39. Sakaguchi S, Sakaguchi N, Asano M, Itoh M, Toda M. Immunologic selftolerance maintained by activated $\mathrm{T}$ cells expressing IL-2 receptor alphachains (CD25). Breakdown of a single mechanism of self-tolerance causes various autoimmune diseases. J Immunol (1995) 155(3):1151-64.

40. Fontenot JD, Gavin MA, Rudensky AY. Foxp3 programs the development and function of CD4+CD25+ regulatory T cells. Nat Immunol (2003) 4(4):330-6. doi:10.1038/ni904

41. Hsieh CS, Zheng Y, Liang Y, Fontenot JD, Rudensky AY. An intersection between the self-reactive regulatory and nonregulatory $\mathrm{T}$ cell receptor repertoires. Nat Immunol (2006) 7(4):401-10. doi:10.1038/ni1318

42. Petzold C, Steinbronn N, Gereke M, Strasser RH, Sparwasser T, Bruder D, et al. Fluorochrome-based definition of naturally occurring Foxp3(+) regulatory T cells of intra- and extra-thymic origin. Eur J Immunol (2014) 44(12):3632-45. doi:10.1002/eji.201444750

43. Viglietta V, Baecher-Allan C, Weiner HL, Hafler DA. Loss of functional suppression by CD4+CD25+ regulatory T cells in patients with multiple sclerosis. J Exp Med (2004) 199(7):971-9. doi:10.1084/jem.20031579

44. International Multiple Sclerosis Genetics Consortium, Hafler DA, Compston A, Sawcer S, Lander ES, Daly MJ, et al. Risk alleles for multiple sclerosis identified by a genomewide study. N Engl J Med (2007) 357(9): 851-62. doi:10.1056/NEJMoa073493

45. International Multiple Sclerosis Genetics Consortium (IMSGC), Beecham AH, Patsopoulos NA, Xifara DK, Davis MF, Kemppinen A, et al. Analysis of immune-related loci identifies 48 new susceptibility variants for multiple sclerosis. Nat Genet (2013) 45(11):1353-60. doi:10.1038/ng.2770

46. Goverman J, Woods A, Larson L, Weiner LP, Hood L, Zaller DM. Transgenic mice that express a myelin basic protein-specific $\mathrm{T}$ cell receptor develop spontaneous autoimmunity. Cell (1993) 72(4):551-60. doi:10.1016/0092-8674 (93) $90074-Z$

47. Waldner H, Whitters MJ, Sobel RA, Collins M, Kuchroo VK. Fulminant spontaneous autoimmunity of the central nervous system in mice transgenic for the myelin proteolipid protein-specific T cell receptor. Proc Natl Acad Sci U S A (2000) 97(7):3412-7. doi:10.1073/pnas.97.7.3412

48. McGeachy MJ, Stephens LA, Anderton SM. Natural recovery and protection from autoimmune encephalomyelitis: contribution of CD4+CD25+ regulatory cells within the central nervous system. J Immunol (2005) 175(5): 3025-32. doi:10.4049/jimmunol.175.5.3025

49. Zhang X, Reddy J, Ochi H, Frenkel D, Kuchroo VK, Weiner HL. Recovery from experimental allergic encephalomyelitis is TGF-beta dependent and associated with increases in $\mathrm{CD} 4+\mathrm{LAP}+$ and $\mathrm{CD} 4+\mathrm{CD} 25+\mathrm{T}$ cells. Int Immunol (2006) 18(4):495-503. doi:10.1093/intimm/dxh390

50. O'Connor RA, Malpass KH, Anderton SM. The inflamed central nervous system drives the activation and rapid proliferation of Foxp3+ regulatory T cells. J Immunol (2007) 179(2):958-66. doi:10.4049/jimmunol.179.2.958

51. Korn T, Reddy J, Gao W, Bettelli E, Awasthi A, Petersen TR, et al. Myelinspecific regulatory $\mathrm{T}$ cells accumulate in the CNS but fail to control autoimmune inflammation. Nat Med (2007) 13(4):423-31. doi:10.1038/nm1564

52. Zhou X, Bailey-Bucktrout SL, Jeker LT, Penaranda C, Martinez-Llordella M, Ashby M, et al. Instability of the transcription factor Foxp3 leads to the generation of pathogenic memory T cells in vivo. Nat Immunol (2009) 10(9): 1000-7. doi:10.1038/ni.1774

53. Bailey-Bucktrout SL, Martinez-Llordella M, Zhou X, Anthony B, Rosenthal W, Luche H, et al. Self-antigen-driven activation induces instability of regulatory $\mathrm{T}$ cells during an inflammatory autoimmune response. Immunity (2013) 39(5):949-62. doi:10.1016/j.immuni.2013.10.016

54. Svet-Moldavskaya IA, Svetmoldavsky GJ. Acquired resistance to experimental allergic encephalomyelitis. Nature (1958) 181(4622):1536-7. doi:10.1038/ $1811536 \mathrm{a} 0$

55. Swierkosz JE, Swanborg RH. Suppressor cell control of unresponsiveness to experimental allergic encephalomyelitis. J Immunol (1975) 115(3):631-3.

56. Rocha B, von Boehmer H. Peripheral selection of the T cell repertoire. Science (1991) 251(4998):1225-8. doi:10.1126/science.1900951

57. Critchfield JM, Racke MK, Zuniga-Pflucker JC, Cannella B, Raine CS, Goverman J, et al. T cell deletion in high antigen dose therapy of autoimmune encephalomyelitis. Science (1994) 263(5150):1139-43. doi:10.1126/ science. 7509084

58. Kennedy MK, Tan LJ, Dal Canto MC, Miller SD. Regulation of the effector stages of experimental autoimmune encephalomyelitis via neuroantigenspecific tolerance induction. J Immunol (1990) 145(1):117-26.

59. Kennedy MK, Tan LJ, Dal Canto MC, Tuohy VK, Lu ZJ, Trotter JL, et al. Inhibition of murine relapsing experimental autoimmune encephalomyelitis by immune tolerance to proteolipid protein and its encephalitogenic peptides. J Immunol (1990) 144(3):909-15.

60. Vandenbark AA, Celnik B, Vainiene M, Miller SD, Offner H. Myelin antigen-coupled splenocytes suppress experimental autoimmune encephalomyelitis in Lewis rats through a partially reversible anergy mechanism. J Immunol (1995) 155(12):5861-7.

61. Turley DM, Miller SD. Peripheral tolerance induction using ethylenecarbodiimide-fixed APCs uses both direct and indirect mechanisms of antigen presentation for prevention of experimental autoimmune encephalomyelitis. J Immunol (2007) 178(4):2212-20. doi:10.4049/jimmunol.178.4.2212

62. Getts DR, Martin AJ, McCarthy DP, Terry RL, Hunter ZN, Yap WT, et al. Microparticles bearing encephalitogenic peptides induce T-cell tolerance and ameliorate experimental autoimmune encephalomyelitis. Nat Biotechnol (2012) 30(12):1217-24. doi:10.1038/nbt.2434

63. Getts DR, Turley DM, Smith CE, Harp CT, McCarthy D, Feeney EM, et al. Tolerance induced by apoptotic antigen-coupled leukocytes is induced by PD-L1+ and IL-10-producing splenic macrophages and maintained by T regulatory cells. J Immunol (2011) 187(5):2405-17. doi:10.4049/jimmunol. 1004175

64. Hawiger D, Masilamani RF, Bettelli E, Kuchroo VK, Nussenzweig MC. Immunological unresponsiveness characterized by increased expression of $\mathrm{CD} 5$ on peripheral $\mathrm{T}$ cells induced by dendritic cells in vivo. Immunity (2004) 20(6):695-705. doi:10.1016/j.immuni.2004.05.002

65. Yu P, Gregg RK, Bell JJ, Ellis JS, Divekar R, Lee HH, et al. Specific T regulatory cells display broad suppressive functions against experimental allergic 
encephalomyelitis upon activation with cognate antigen. J Immunol (2005) 174(11):6772-80. doi:10.4049/jimmunol.174.11.6772

66. Stern JN, Keskin DB, Kato Z, Waldner H, Schallenberg S, Anderson A, et al. Promoting tolerance to proteolipid protein-induced experimental autoimmune encephalomyelitis through targeting dendritic cells. Proc Natl Acad Sci U S A (2010) 107(40):17280-5. doi:10.1073/pnas.1010263107

67. Yogev N, Frommer F, Lukas D, Kautz-Neu K, Karram K, Ielo D, et al. Dendritic cells ameliorate autoimmunity in the CNS by controlling the homeostasis of PD-1 receptor(+) regulatory T cells. Immunity (2012) 37(2):264-75. doi:10.1016/j.immuni.2012.05.025

68. Idoyaga J, Fiorese C, Zbytnuik L, Lubkin A, Miller J, Malissen B, et al. Specialized role of migratory dendritic cells in peripheral tolerance induction. J Clin Invest (2013) 123(2):844-54. doi:10.1172/JCI65260

69. Kretschmer K, Apostolou I, Hawiger D, Khazaie K, Nussenzweig MC, von Boehmer $\mathrm{H}$. Inducing and expanding regulatory $\mathrm{T}$ cell populations by foreign antigen. Nat Immunol (2005) 6(12):1219-27. doi:10.1038/ni1265

70. Coombes JL, Siddiqui KR, Arancibia-Carcamo CV, Hall J, Sun CM, Belkaid Y, et al. A functionally specialized population of mucosal CD103+ DCs induces Foxp3+ regulatory T cells via a TGF-beta and retinoic acid-dependent mechanism. J Exp Med (2007) 204(8):1757-64. doi:10.1084/jem.20070590

71. Sun CM, Hall JA, Blank RB, Bouladoux N, Oukka M, Mora JR, et al. Small intestine lamina propria dendritic cells promote de novo generation of Foxp3 T reg cells via retinoic acid. J Exp Med (2007) 204(8):1775-85. doi:10.1084/ jem.20070602

72. Hadeiba H, Sato T, Habtezion A, Oderup C, Pan J, Butcher EC. CCR9 expression defines tolerogenic plasmacytoid dendritic cells able to suppress acute graft-versus-host disease. Nat Immunol (2008) 9(11):1253-60. doi:10.1038/ ni. 1658

73. Yamazaki S, Dudziak D, Heidkamp GF, Fiorese C, Bonito AJ, Inaba K, et al. CD8+ CD205+ splenic dendritic cells are specialized to induce Foxp3+ regulatory T cells. J Immunol (2008) 181(10):6923-33. doi:10.4049/ jimmunol.181.10.6923

74. Darrasse-Jeze G, Deroubaix S, Mouquet H, Victora GD, Eisenreich T, Yao KH, et al. Feedback control of regulatory T cell homeostasis by dendritic cells in vivo. J Exp Med (2009) 206(9):1853-62. doi:10.1084/jem.20090746

75. Josefowicz SZ, Niec RE, Kim HY, Treuting P, Chinen T, Zheng Y, et al. Extrathymically generated regulatory $\mathrm{T}$ cells control mucosal TH2 inflammation. Nature (2012) 482(7385):395-9. doi:10.1038/nature10772

76. Ring S, Maas M, Nettelbeck DM, Enk AH, Mahnke K. Targeting of autoantigens to DEC205(+) dendritic cells in vivo suppresses experimental allergic encephalomyelitis in mice. J Immunol (2013) 191(6):2938-47. doi:10.4049/ jimmunol.1202592

77. Hawiger D, Wan YY, Eynon EE, Flavell RA. The transcription cofactor Hopx is required for regulatory $\mathrm{T}$ cell function in dendritic cell-mediated peripheral T cell unresponsiveness. Nat Immunol (2010) 11(10):962-8. doi:10.1038/ ni. 1929

78. Jones A, Opejin A, Henderson JG, Gross C, Jain R, Epstein JA, et al. Peripherally induced tolerance depends on peripheral regulatory $\mathrm{T}$ cells that require Hopx to inhibit intrinsic IL-2 expression. J Immunol (2015) 195(4):1489-97. doi:10.4049/jimmunol.1500174

79. Jones A, Bourque J, Kuehm L, Opejin A, Teague RM, Gross C, et al. Immunomodulatory functions of BTLA and HVEM govern induction of extrathymic regulatory $\mathrm{T}$ cells and tolerance by dendritic cells. Immunity (2016) 45(5):1066-77. doi:10.1016/j.immuni.2016.10.008

80. Henderson JG, Opejin A, Jones A, Gross C, Hawiger D. CD5 instructs extrathymic regulatory $\mathrm{T}$ cell development in response to self and tolerizing antigens. Immunity (2015) 42(3):471-83. doi:10.1016/j.immuni.2015.02.010

81. Curotto de Lafaille MA, Kutchukhidze N, Shen S, Ding Y, Yee H, Lafaille JJ. Adaptive Foxp3+ regulatory T cell-dependent and -independent control ofallergicinflammation.Immunity (2008) 29(1):114-26.doi:10.1016/j. immuni.2008.05.010

82. Haribhai D, Williams JB, Jia S, Nickerson D, Schmitt EG, Edwards B, et al. A requisite role for induced regulatory $T$ cells in tolerance based on expanding antigen receptor diversity. Immunity (2011) 35(1):109-22. doi:10.1016/j. immuni.2011.03.029

83. Lathrop SK, Bloom SM, Rao SM, Nutsch K, Lio CW, Santacruz N, et al. Peripheral education of the immune system by colonic commensal microbiota. Nature (2011) 478(7368):250-4. doi:10.1038/nature10434
84. Samstein RM, Josefowicz SZ, Arvey A, Treuting PM, Rudensky AY. Extrathymic generation of regulatory $\mathrm{T}$ cells in placental mammals mitigates maternal-fetal conflict. Cell (2012) 150(1):29-38. doi:10.1016/j.cell.2012. 05.031

85. Steinman RM, Hawiger D, Nussenzweig MC. Tolerogenic dendritic cells. Annu Rev Immunol (2003) 21:685-711. doi:10.1146/annurev.immunol.21. 120601.141040

86. Steinman RM. Decisions about dendritic cells: past, present, and future. Annu RevImmunol (2012) 30:1-22. doi:10.1146/annurev-immunol-100311-102839

87. Durai V, Murphy KM. Functions of murine dendritic cells. Immunity (2016) 45(4):719-36. doi:10.1016/j.immuni.2016.10.010

88. Wang L, Li Z, Ciric B, Safavi F, Zhang GX, Rostami A. Selective depletion of CD11c+ CD11b+ dendritic cells partially abrogates tolerogenic effects of intravenous MOG in murine EAE. Eur J Immunol (2016) 46(10):2454-66. doi:10.1002/eji.201546274

89. Hawiger D, Inaba K, Dorsett Y, Guo M, Mahnke K, Rivera M, et al. Dendritic cells induce peripheral $\mathrm{T}$ cell unresponsiveness under steady state conditions in vivo. J Exp Med (2001) 194(6):769-79. doi:10.1084/jem.194.6.769

90. Probst HC, Lagnel J, Kollias G, van den Broek M. Inducible transgenic mice reveal resting dendritic cells as potent inducers of CD8+ T cell tolerance. Immunity (2003) 18(5):713-20. doi:10.1016/S1074-7613(03)00120-1

91. Ohnmacht C, Pullner A, King SB, Drexler I, Meier S, Brocker T, et al. Constitutive ablation of dendritic cells breaks self-tolerance of $\mathrm{CD} 4 \mathrm{~T}$ cells and results in spontaneous fatal autoimmunity. J Exp Med (2009) 206(3):549-59. doi:10.1084/jem.20082394

92. Huang YM, Yang JS, Xu LY, Link H, Xiao BG. Autoantigen-pulsed dendritic cells induce tolerance to experimental allergic encephalomyelitis (EAE) in Lewis rats. Clin Exp Immunol (2000) 122(3):437-44. doi:10.1046/j.1365-2249. 2000.01398.x

93. Legge KL, Gregg RK, Maldonado-Lopez R, Li L, Caprio JC, Moser M, et al. On the role of dendritic cells in peripheral T cell tolerance and modulation of autoimmunity. J Exp Med (2002) 196(2):217-27. doi:10.1084/jem.20011061

94. Menges M, Rossner S, Voigtlander C, Schindler H, Kukutsch NA, Bogdan C, et al. Repetitive injections of dendritic cells matured with tumor necrosis factor alpha induce antigen-specific protection of mice from autoimmunity. J Exp Med (2002) 195(1):15-21. doi:10.1084/jem.20011341

95. Paterka M, Voss JO, Werr J, Reuter E, Franck S, Leuenberger T, et al. Dendritic cells tip the balance towards induction of regulatory $\mathrm{T}$ cells upon priming in experimental autoimmune encephalomyelitis. JAutoimmun (2017) 76: 108-14. doi:10.1016/j.jaut.2016.09.008

96. Munn DH, Sharma MD, Lee JR, Jhaver KG, Johnson TS, Keskin DB, et al. Potential regulatory function of human dendritic cells expressing indoleamine 2,3-dioxygenase. Science (2002) 297(5588):1867-70. doi:10.1126/science. 1073514

97. Mucida D, Park Y, Kim G, Turovskaya O, Scott I, Kronenberg M, et al. Reciprocal TH17 and regulatory T cell differentiation mediated by retinoic acid. Science (2007) 317(5835):256-60. doi:10.1126/science.1145697

98. Li MO, Flavell RA. Contextual regulation of inflammation: a duet by transforming growth factor-beta and interleukin-10. Immunity (2008) 28(4):468-76. doi:10.1016/j.immuni.2008.03.003

99. Manicassamy S, Ravindran R, Deng J, Oluoch H, Denning TL, Kasturi SP, et al. Toll-like receptor 2-dependent induction of vitamin A-metabolizing enzymes in dendritic cells promotes $\mathrm{T}$ regulatory responses and inhibits autoimmunity. Nat Med (2009) 15(4):401-9. doi:10.1038/nm.1925

100. Mascanfroni ID, Yeste A, Vieira SM, Burns EJ, Patel B, Sloma I, et al. IL-27 acts on DCs to suppress the $\mathrm{T}$ cell response and autoimmunity by inducing expression of the immunoregulatory molecule CD39. Nat Immunol (2013) 14(10):1054-63. doi:10.1038/ni.2695

101. Probst HC, McCoy K, Okazaki T, Honjo T, van den Broek M. Resting dendritic cells induce peripheral CD8+ T cell tolerance through PD-1 and CTLA-4. Nat Immunol (2005) 6(3):280-6. doi:10.1038/ni1165

102. Wang L, Pino-Lagos K, de Vries VC, Guleria I, Sayegh MH, Noelle RJ. Programmed death 1 ligand signaling regulates the generation of adaptive Foxp3+CD4+ regulatory T cells. Proc Natl Acad Sci U S A (2008) 105(27): 9331-6. doi:10.1073/pnas.0710441105

103. Wing K, Onishi Y, Prieto-Martin P, Yamaguchi T, Miyara M, Fehervari Z, et al. CTLA-4 control over Foxp3+ regulatory T cell function. Science (2008) 322(5899):271-5. doi:10.1126/science. 1160062 
104. Fife BT, Pauken KE, Eagar TN, Obu T, Wu J, Tang Q, et al. Interactions between PD-1 and PD-L1 promote tolerance by blocking the TCR-induced stop signal. Nat Immunol (2009) 10(11):1185-92. doi:10.1038/ni.1790

105. Francisco LM, Salinas VH, Brown KE, Vanguri VK, Freeman GJ, Kuchroo VK, et al. PD-L1 regulates the development, maintenance, and function of induced regulatory T cells. J Exp Med (2009) 206(13):3015-29. doi:10.1084/jem.20090847

106. Apostolou I, von Boehmer H. In vivo instruction of suppressor commitment in naive T cells. J Exp Med (2004) 199(10):1401-8. doi:10.1084/jem.20040249

107. Gottschalk RA, Corse E, Allison JP. TCR ligand density and affinity determine peripheral induction of Foxp3 in vivo. J Exp Med (2010) 207(8):1701-11. doi:10.1084/jem.20091999

108. Azzam HS, Grinberg A, Lui K, Shen H, Shores EW, Love PE. CD5 expression is developmentally regulated by T cell receptor (TCR) signals and TCR avidity. J Exp Med (1998) 188(12):2301-11. doi:10.1084/jem.188.12.2301

109. Soldevila G, Raman C, Lozano F. The immunomodulatory properties of the CD5 lymphocyte receptor in health and disease. Curr Opin Immunol (2011) 23(3):310-8. doi:10.1016/j.coi.2011.03.003

110. Mandl JN, Monteiro JP, Vrisekoop N, Germain RN. T cell-positive selection uses self-ligand binding strength to optimize repertoire recognition of foreign antigens. Immunity (2013) 38(2):263-74. doi:10.1016/j.immuni.2012.09.011

111. Klein L, Kyewski B, Allen PM, Hogquist KA. Positive and negative selection of the T cell repertoire: what thymocytes see (and don't see). Nat Rev Immunol (2014) 14(6):377-91. doi:10.1038/nri3667

112. Josefowicz SZ, Lu LF, Rudensky AY. Regulatory T cells: mechanisms of differentiation and function. Annu Rev Immunol (2012) 30:531-64. doi:10.1146/ annurev.immunol.25.022106.141623

113. Shevach EM, Thornton AM. tTregs, pTregs, and iTregs: similarities and differences. Immunol Rev (2014) 259(1):88-102. doi:10.1111/imr.12160

114. Dhainaut M, Coquerelle C, Uzureau S, Denoeud J, Acolty V, Oldenhove $\mathrm{G}$, et al. Thymus-derived regulatory $\mathrm{T}$ cells restrain proinflammatory Th1 responses by downregulating CD70 on dendritic cells. EMBO J (2015) 34(10):1336-48. doi:10.15252/embj.201490312

115. Huan J, Culbertson N, Spencer L, Bartholomew R, Burrows GG, Chou YK, et al. Decreased FOXP3 levels in multiple sclerosis patients. J Neurosci Res (2005) 81(1):45-52. doi:10.1002/jnr.20522

116. Sellebjerg F, Krakauer M, Khademi M, Olsson T, Sorensen PS. FOXP3, CBLB and ITCH gene expression and cytotoxic T lymphocyte antigen 4 expression on CD4(+) CD25(high) T cells in multiple sclerosis. Clin Exp Immunol (2012) 170(2):149-55. doi:10.1111/j.1365-2249.2012.04654.x

117. Kobie JJ, Shah PR, Yang L, Rebhahn JA, Fowell DJ, Mosmann TR. T regulatory and primed uncommitted CD4 T cells express CD73, which suppresses effector $\mathrm{CD} 4 \mathrm{~T}$ cells by converting 5 '-adenosine monophosphate to adenosine. J Immunol (2006) 177(10):6780-6. doi:10.4049/jimmunol.177.10.6780

118. Bopp T, Becker C, Klein M, Klein-Hessling S, Palmetshofer A, Serfling E, et al. Cyclic adenosine monophosphate is a key component of regulatory T cell-mediated suppression. J Exp Med (2007) 204(6):1303-10. doi:10.1084/ jem.20062129

119. Borsellino G, Kleinewietfeld M, Di Mitri D, Sternjak A, Diamantini A, Giometto R, et al. Expression of ectonucleotidase CD39 by Foxp3+ Treg cells: hydrolysis of extracellular ATP and immune suppression. Blood (2007) 110(4):1225-32. doi:10.1182/blood-2006-12-064527

120. Deaglio S, Dwyer KM, Gao W, Friedman D, Usheva A, Erat A, et al. Adenosine generation catalyzed by $\mathrm{CD} 39$ and $\mathrm{CD} 73$ expressed on regulatory T cells mediates immune suppression. J Exp Med (2007) 204(6):1257-65. doi:10.1084/jem.20062512

121. Niemela J, Ifergan I, Yegutkin GG, Jalkanen S, Prat A, Airas L. IFN-beta regulates CD73 and adenosine expression at the blood-brain barrier. Eur J Immunol (2008) 38(10):2718-26. doi:10.1002/eji.200838437

122. Fletcher JM, Lonergan R, Costelloe L, Kinsella K, Moran B, O’Farrelly C, et al. CD39+Foxp3+ regulatory $\mathrm{T}$ Cells suppress pathogenic Th17 cells and are impaired in multiple sclerosis. J Immunol (2009) 183(11):7602-10. doi:10.4049/jimmunol.0901881

123. Dwyer KM, Hanidziar D, Putheti P, Hill PA, Pommey S, McRae JL, et al. Expression of CD39 by human peripheral blood $\mathrm{CD} 4+\mathrm{CD} 25+\mathrm{T}$ cells denotes a regulatory memory phenotype. Am J Transplant (2010) 10(11):2410-20. doi:10.1111/j.1600-6143.2010.03291.x

124. Doherty GA, Bai A, Hanidziar D, Longhi MS, Lawlor GO, Putheti P, et al. CD73 is a phenotypic marker of effector memory Th17 cells in inflammatory bowel disease. Eur JImmunol (2012) 42(11):3062-72. doi:10.1002/eji. 201242623

125. Allard B, Longhi MS, Robson SC, Stagg J. The ectonucleotidases CD39 and CD73: novel checkpoint inhibitor targets. Immunol Rev (2017) 276(1):121-44. doi:10.1111/imr.12528

126. Sabatos CA, Chakravarti S, Cha E, Schubart A, Sanchez-Fueyo A, Zheng XX, et al. Interaction of Tim-3 and Tim-3 ligand regulates T helper type 1 responses and induction of peripheral tolerance. Nat Immunol (2003) 4(11):1102-10. doi:10.1038/ni988

127. Sanchez-Fueyo A, Tian J, Picarella D, Domenig C, Zheng XX, Sabatos CA, et al. Tim-3 inhibits $\mathrm{T}$ helper type 1-mediated auto- and alloimmune responses and promotes immunological tolerance. Nat Immunol (2003) 4(11): 1093-101. doi:10.1038/ni987

128. Huang CT, Workman CJ, Flies D, Pan X, Marson AL, Zhou G, et al. Role of LAG-3 in regulatory T cells. Immunity (2004) 21(4):503-13. doi:10.1016/j. immuni.2004.08.010

129. Liang B, Workman C, Lee J, Chew C, Dale BM, Colonna L, et al. Regulatory $\mathrm{T}$ cells inhibit dendritic cells by lymphocyte activation gene- 3 engagement of MHC class II. J Immunol (2008) 180(9):5916-26. doi:10.4049/jimmunol. 180.9.5916

130. Sarris M, Andersen KG, Randow F, Mayr L, Betz AG. Neuropilin-1 expression on regulatory $\mathrm{T}$ cells enhances their interactions with dendritic cells during antigen recognition. Immunity (2008) 28(3):402-13. doi:10.1016/j. immuni.2008.01.012

131. Yu X, Harden K, Gonzalez LC, Francesco M, Chiang E, Irving B, et al. The surface protein TIGIT suppresses $\mathrm{T}$ cell activation by promoting the generation of mature immunoregulatory dendritic cells. Nat Immunol (2009) 10(1):48-57. doi:10.1038/ni.1674

132. Solomon BD, Mueller C, Chae WJ, Alabanza LM, Bynoe MS. Neuropilin-1 attenuates autoreactivity in experimental autoimmune encephalomyelitis. Proc Natl Acad Sci U S A (2011) 108(5):2040-5. doi:10.1073/pnas.1008721108

133. Gupta S, Thornley TB, Gao W, Larocca R, Turka LA, Kuchroo VK, et al. Allograft rejection is restrained by short-lived TIM-3+PD-1+Foxp3+ Tregs. J Clin Invest (2012) 122(7):2395-404. doi:10.1172/JCI45138

134. Lozano E, Dominguez-Villar M, Kuchroo V, Hafler DA. The TIGIT/CD226 axis regulates human $\mathrm{T}$ cell function. J Immunol (2012) 188(8):3869-75. doi:10.4049/jimmunol.1103627

135. Gautron AS, Dominguez-Villar M, de Marcken M, Hafler DA. Enhanced suppressor function of TIM-3+ FoxP3+ regulatory T cells. Eur J Immunol (2014) 44(9):2703-11. doi:10.1002/eji.201344392

136. Joller N, Lozano E, Burkett PR, Patel B, Xiao S, Zhu C, et al. Treg cells expressing the coinhibitory molecule TIGIT selectively inhibit proinflammatory Th1 and Th17 cell responses. Immunity (2014) 40(4):569-81. doi:10.1016/j. immuni.2014.02.012

137. Kurtulus S, Sakuishi K, Ngiow SF, Joller N, Tan DJ, Teng MW, et al. TIGIT predominantly regulates the immune response via regulatory $\mathrm{T}$ cells. J Clin Invest (2015) 125(11):4053-62. doi:10.1172/JCI81187

138. Schmidt A, Oberle N, Weiss EM, Vobis D, Frischbutter S, Baumgrass R, et al. Human regulatory $\mathrm{T}$ cells rapidly suppress $\mathrm{T}$ cell receptor-induced $\mathrm{Ca}(2+), \mathrm{NF}-\mathrm{kappaB}$, and NFAT signaling in conventional T cells. Sci Signal (2011) 4(204):ra90. doi:10.1126/scisignal.2002179

139. Schwarz A, Schumacher M, Pfaff D, Schumacher K, Jarius S, Balint B, et al. Fine-tuning of regulatory $\mathrm{T}$ cell function: the role of calcium signals and naive regulatory $\mathrm{T}$ cells for regulatory $\mathrm{T}$ cell deficiency in multiple sclerosis. J Immunol (2013) 190(10):4965-70. doi:10.4049/jimmunol.1203224

140. Dominguez-Villar M, Baecher-Allan CM, Hafler DA. Identification of $\mathrm{T}$ helper type 1-like, Foxp3+ regulatory $\mathrm{T}$ cells in human autoimmune disease. Nat Med (2011) 17(6):673-5. doi:10.1038/nm.2389

141. Boyman O, Kovar M, Rubinstein MP, Surh CD, Sprent J. Selective stimulation of T cell subsets with antibody-cytokine immune complexes. Science (2006) 311(5769):1924-7. doi:10.1126/science.1122927

142. Tang Q, Adams JY, Penaranda C, Melli K, Piaggio E, Sgouroudis E, et al. Central role of defective interleukin-2 production in the triggering of islet autoimmune destruction. Immunity (2008) 28(5):687-97. doi:10.1016/j. immuni.2008.03.016

143. Webster KE, Walters S, Kohler RE, Mrkvan T, Boyman O, Surh CD, et al. In vivo expansion of $\mathrm{T}$ reg cells with IL-2-mAb complexes: induction of resistance to EAE and long-term acceptance of islet allografts without immunosuppression. J Exp Med (2009) 206(4):751-60. doi:10.1084/jem.20082824 
144. Malek TR, Castro I. Interleukin-2 receptor signaling: at the interface between tolerance and immunity. Immunity (2010) 33(2):153-65. doi:10.1016/j. immuni.2010.08.004

145. Grigorian A, Mkhikian H, Demetriou M. Interleukin-2, interleukin-7, T cell-mediated autoimmunity, and N-glycosylation. Ann N Y Acad Sci (2012) 1253:49-57. doi:10.1111/j.1749-6632.2011.06391.x

146. Kim MG, Koo TY, Yan JJ, Lee E, Han KH, Jeong JC, et al. IL-2/anti-IL-2 complex attenuates renal ischemia-reperfusion injury through expansion of regulatory T cells. J Am Soc Nephrol (2013) 24(10):1529-36. doi:10.1681/ ASN.2012080784

147. Pierson W, Cauwe B, Policheni A, Schlenner SM, Franckaert D, Berges J, et al. Antiapoptotic Mcl-1 is critical for the survival and niche-filling capacity of Foxp3(+) regulatory T cells. Nat Immunol (2013) 14(9):959-65. doi:10.1038/ ni.2649

148. Carbone F, De Rosa V, Carrieri PB, Montella S, Bruzzese D, Porcellini A, et al. Regulatory $\mathrm{T}$ cell proliferative potential is impaired in human autoimmune disease. Nat Med (2014) 20(1):69-74. doi:10.1038/nm.3411

149. Goodin DS, Frohman EM, Garmany GP Jr, Halper J, Likosky WH, Lublin FD, et al. Disease modifying therapies in multiple sclerosis: report of the therapeutics and technology assessment subcommittee of the American Academy of Neurology and the MS council for Clinical Practice Guidelines. Neurology (2002) 58(2):169-78. doi:10.1212/WNL.58.2.169
150. Goodin DS. Disease-modifying therapy in multiple sclerosis: update and clinical implications. Neurology (2008) 71(24 Suppl 3):S8-13. doi:10.1212/ WNL.0b013e31818f3d8b

151. Harrison DM. In the clinic. Multiple sclerosis. Ann Intern Med (2014) 160(7): ITC4-2-ITC4-18; quiz ITC14-16. doi:10.7326/0003-4819-160-7-20140401001004

152. Mastorodemos V, Ioannou M, Verginis P. Cell-based modulation of autoimmune responses in multiple sclerosis and experimental autoimmmune encephalomyelitis: therapeutic implications. Neuroimmunomodulation (2015) 22(3):181-95. doi:10.1159/000362370

Conflict of Interest Statement: The authors declare that the research was conducted in the absence of any commercial or financial relationships that could be construed as a potential conflict of interest.

Copyright (C) 2017 Jones and Hawiger. This is an open-access article distributed under the terms of the Creative Commons Attribution License (CC BY). The use, distribution or reproduction in other forums is permitted, provided the original author $(s)$ or licensor are credited and that the original publication in this journal is cited, in accordance with accepted academic practice. No use, distribution or reproduction is permitted which does not comply with these terms. 